\title{
Saying No as Expressed in English and Javanese Communication
}

\author{
Adnan Zaid
}

Universitas Teknologi Yogyakarta

\begin{abstract}
In a normal atmosphere of communication, not in madness, anger or annoyance, people exert their efforts not to lose their face and not to hurt their interlocutor's feeling. They try to do their best to make their interlocutors feel convenient and secured. This phenomenon can be found even when people refuse, disagree, and reject someone's idea. Certain words, phrases or sentences may be uttered in such a way that the interlocutor retains his/her good mood for further communication. The failure to employ the right words or expression may result in miscommunication.

This paper tries to explore how saying no is expressed in Javanese and English. It is aimed at finding out the words, phrases and sentences which are employed to express denial, ranging from the blunt up to the polite ones. Some similarities and differences will be investigated. Both Javanese and English people are popular for being polite wheninteracting verbally. So it is going to be interesting to know how people say no in the two different languages. In this article some kind of universality in saying no will also be sought.
\end{abstract}

Keywords: language, saying no, English, Javanese

\section{INTRODUCTION}

In order to run smooth communication people endeavor to make their interlocutors feel secured, free from being threatened or hurt. This phenomenon may still occur even when people disagree, refuse, deny, and the like. Certain linguistic strategies may be made to avoid offending or hurting interlocutors. English and Javanese are no exception in this case. Although Indonesia and UK are geographically far away apart, English and Indonesian may show some similarities in saying no. Certain polite strategies may be employed for certain communicative purposes in both languages. Surely, there will be some differences due to different cultures because language and culture are interrelated. To some extent, people will do their best to communicate verbally because their language will show who they are. In English there is a proverb saying "Words are mightier than a sword", meaning that people have to be very cautious with their words used in communication. Otherwise, their interlocutors may feel hurt or unsecured. In Javanese, there is a principle of respecting and living in harmony (Magnis-Suseno, 1985:38). So Javanese will be very careful with their words to maintain the harmony. In Javanese there is a proverb "Ajining diri gumantung anainglati" (One's dignity depends on his/her lips), meaning that one has to be very careful in what he/she says if he/she wants to be respected.

\section{SAYING No}

In communication people do their best not to lose their face. In other words, they, linguistically, will employ certain words, phrases, or sentences to be modest. This is realized in certain polite linguistic devices for certain occasions such as requests, offers, compliments, apologies, thanks, greetings, leave takings, addressing, and the responses to these. Even, this phenomenon occurs when one wants to say no, disagree, deny, or refuse. Foley (2001) points out that politeness is a battery of social interaction skills whose goal is to ensure everyone feels affirmed in social interaction. Brown and Levinson (1987) argue that politeness strategies are developed in order to save the hearer's "face", meaning that people try to avoid embarrassing the other persons, or making them feel uncomfortable. Linguistically, people avoid conflict which may generate from verbal communication, even when they have to say no.

\subsection{In Javanese}

Javanese people have a principle of living in harmony. One has to behave in such a way that he/she will not create a conflict (Magnis-Suseno, 1985). This phenomenon is seen, among others, in the way 
Javanese people use language. Javanese people have to be careful in using language so that they will not create any conflict, maintaining the principle of living in harmony. Here are some examples of saying no in Javanese.

\subsubsection{Saying No Bluntly}

Among friends, saying no can be done bluntly, in the sense that being very polite is not so important. For example:

Tarno: Arepmelunggaraptugasbarengora? (Will you join us to do the assignment together?)

Budi: Ora. Akutaksinaudhewewae. (No. I will study alone.)

In this context, Budi says no directly, but he gives the reason for not joining Tarno. Since Tarno and Budi are friends, saying no without using a polite marker is acceptable.

\subsubsection{Saying No Indirectly}

Oftentimes, a Javanese person will not frontally say no to his/her interlocutor. Instead, he/she may give some reasons, not just saying no. For example:

Mr. Bardi: Panjenenganmakilikulanggih Pak? (You represent me, won’t you, Sir?)

Mr. Sardi: MboksanesemawonPak. Kula napapantesmakilipanjenengan? (Please choose another person, Sir. Am I the right person to represent you?)

\subsubsection{Declining}

In declining something a Javanese may apologize such as by saying "Nyuwunngapunten" (Please forgive me), or "Nuwunsewu" (I am sorry). He or she does not say no directly.

Pak Tukiran: Panjenengansagedndherektuwi Bu Tutik ta? (Could you go with us to visit MsTutik?)

Pak Joko: Nyuwunngapunten. Kula wontenpedamelansanes. (I'm sorry. I have got something else to do.)

In this dialogue Pak Joko does not directly say no. To make it modest, he apologizes and gives a reason for not being able to do as requested.

\subsubsection{Disagreeing}

In disagreeing, a Javanese will not directly express his/her disagreement. He/she apologizes first, and then he/she says something related to his/her opinion. For example:

JengNdari: Wahsragamekoklarangya? (The uniform is expensive, isn't it?)

Jeng Nana: Nek nurutakukokyaralarang. Biasawae. (In my opinion, it is not so expensive. It is just reasonable.)

Jeng Nana does not respond negatively to Jeng Ndari's opinion by saying no. Instead, she just expresses her own idea about the topic.

\subsection{In English}

\subsubsection{Saying No Directly}

Among friends or from a superior to a subordinate, it is common to say no directly.

For example:

Jack: Did you come to the meeting yesterday?

Jimmy: No, I did not.

In this dialog, Jimmy replies by saying no directly. It can be predicted that Jimmy knows Jack very well so that he can say no directly without any polite marker. However, in most cases people will not say no directly. Instead, they will apply some polite markers to make their communication convenient.

\subsubsection{Saying No Indirectly}

In order not to hurt the interlocutor's feeling, some expressions are used to say no as to decline, or to disagree. In saying no, one does not directly say no. Instead, he/she will say some expressions such as: 
I'd love to, but ...

I really appreciate the offer, but ...

That sounds great, but ...

I'm afraid I can't ...

I'm not really fond of ...

Thank you very much, but I have to ...

That's a good idea, but ...

I think it is too ... to ...

\subsubsection{Disagreeing}

To disagree with someone, a civil society demands someone to express disagreement in a polite way to minimize any inconvenience. To say "I disagree" is too direct. Instead, one may use the following expressions for this purpose:

I'm afraid I disagree.

I beg to differ.

I am not sure about that.

Not necessarily.

I don't see it that way.

I'm sorry but I don't agree.

Yes, but ...

Well, in my opinion ...

Actually, I think ...

\subsubsection{Declining}

In declining an invitation, one does not say no directly. Instead he/she may use certain expressions such as :

Thank you very much for the invitation, but I have to ...

That's great, but I ...

I'm so sorry, but I ...

Thank you for inviting me to .... Unfortunately, I ...

\section{Similarities AND DifFERENCES}

Although Javanese and English are spoken by their native speakers living far away from each other, the two languages share something in common in relation to saying no. There are some words, phrases or sentences in both languages, which are utilized to minimize any conflict due to verbal communication.

In English, some special expressions are employed to say no in order to decline, or to disagree politely. In Javanese, indirectness plays an important role to minimize any conflict. Besides, the phrases "Nyuwunngapunten"(Forgive me) and "Nuwunsewu" (I am sorry) are mostly used to say no for the sake of declining, or disagreeing. Among Javanese, kramamadya (middle level of the language) and kramainggil (high level of the language) may be employed to be polite in saying no. The use of this kind of level in language is not found in English.

\section{Concluding Remark}

To get along with other people harmoniously and to avoid conflict in communication, linguistically civilized people employ some strategies. The strategies can lie on the form of some special expressions to show some kind of politeness, or on the form of a certain level of language. Even when 
has to say no, he/she has to be very careful in choosing certain polite markers. The above phenomenon is found in English and Javanese. There are some similar strategies to say no in both languages. In the two languages, some special expressions are employed for the purpose. In Javanese, there is a tendency not to say no directly. Instead, an apology is uttered to show politeness and at the same time to avoid any possible conflict. In Javanese, the words nuwunsewu (I am sorry) and nyuwunpangapunten (Forgive me) are used to say no, to decline or to disagree. In English, the words I am sorry or I am afraid are employed to serve the same purpose.

\section{REFERENCES}

Brown, P. and Levinson, C. (1987).Politeness: Some Universals in Language Usage.

Cambridge: Cambridge University Press.

Foley, W. A. (2001). Anthropological Linguistics: An Introduction. Oxford: Blackwell Publishers.

Magnis-Suseno, F. 1985.EtikaJawa. Jakarta: Gramedia.

1997. Javanese Ethics and World-View. Jakarta: PT Gramedia Pustaka Utama

Mulder, N. 1983. Java-Thailand: A Comparative Perspective. Yogyakarta: GadjahMada University Press.

2006. Doing Java: An Anthropological Detective Story. Yogyakarta: Penerbit Kanisius

Pranowo, (2009).BerbahasaSecaraSantun. Yogyakarta: PustakaPelajar. 